\section{Gay and Lesbian Political Science Caucus Formed}

During the 1988 APSA Annual Meeting in Washington, DC, a Gay and Lesbian Political Science Caucus was formed. Its objectives include organizing or sponsoring presentations on gay and lesbian topics at APSA meetings, working for equity for gay men and lesbians within the profession, and providing a support network for them. Elected to co-chair the caucus were Mark Blasius (City University of New York) and Sarah Slavin (State University of New York College at Buffalo). Two panels, one on sodomy laws and one on issues in gay and lesbian political research, and possibly a workshop on homophobia in the profession, are planned for the 1989 annual meeting in Atlanta. People interested in making presentations in Atlanta, or in participating in the caucus in other ways, may write to Mark Blasius, 429 West 46th Street, Apartment 6-D, New York, NY 10036; or Sarah Slavin, 736 Ashland Avenue, Buffalo, NY 14222.

\section{Inviting Applications for Seminars on The Bill of Rights and Civil Rights at 1989 Annual Meeting}

A faculty development project designed to enhance inquiry and teaching on the Bill of Rights and civil rights will be offered to college faculty in conjunction with the 1989 Annual Meeting. The project is supported by a grant from the Ford Foundation.

Participants in the project will be able to strengthen their presentations and assignments on the history and politics of civil rights in their American government courses. The program offers participants a choice among four short seminars prior to the 1989 APSA Annual Meeting. The titles and directors of the seminars are:

"Landmarks in Judicial Interpretation of Civil Rights in America," directed by Henry ]. Abraham, University of Virginia.

"The Concept of Rights as Limits on Government," directed by Jennifer Nedelsky, University of Toronto.

"Civil Rights and Social Change: The Contributions of Interest Groups, Social Movements and the Courts," directed by Karen O'Connor, Emory University.

"The Philosophical Roots of the Bill of Rights: The Federalists' and AntiFederalists' Conceptions of Rights," directed by Tom Pangle, University of Toronto.

Complete descriptions of the four seminars are published in the fall issue of The Political Science Teacher.

Seminar participants will also attend panels offered in two special sections of the 1989 Annual Meeting Program Committee-the sections devoted to the Bill of Rights in honor of its bicentennial and The Civil Rights Act of 1964 in observance of its twenty-fifth anniversary.

\section{Arrangements}

Faculty selected to participate in the seminars will receive travel support and living expenses for the duration of the seminars and the Annual Meeting, from Sunday, August 27, until Sunday, September 3, 1989. Participants will have accommodations that week at the Atlanta Hilton, headquarters for the 1989 APSA Annual Meeting.

\section{To Apply}

Faculty wishing to participate in the program should apply by submitting a curriculum vitae along with a letter indicating:

1. a first and second choice of seminar. 
2. expectations of benefits from participating in the project.

3. a description of courses taught and how participation might be used in revising course syllabi, presentations and assignments.

Please send the curriculum vitae and letter by February 15, 1989, to: "Civil Rights in America," American Political Science Association, 1527 New Hampshire Avenue, NW, Washington, DC 20036.

Applicants will be notified of selection by April 1989.

\section{Annual Meeting}

\section{Policies and Deadlines}

Paper proposals and offers to appear as discussants or panel chairpersons must be submitted as early as possible. The deadline for receipt of submissions is December 1. 1988. Proposals for whole panels are welcome, but persons with suggestions for panels should get their requests in early.

Please write directly to the appropriate section chairperson listed below. More general inquiries or suggestions may be addressed to:

Nelson W. Polsby, Department of Political Science, University of California, Berkeley, CA 94720; (415) 6426323 (Program Chair).

Norinne Hessman or Ann Peyser, APSA, 1527 New Hampshire Avenue, NW, Washington, DC 20036; (202) 483-2512.

Prospective participants should be aware of two APSA Council policies:

(1) Acceptance of a proposal by the Program Committee obligates you to preregister (with appropriate fee) prior to June 1, 1989. If you fail to preregister, you will not be listed in the final program.

(2) Participants may appear on two (but no more than two) panels in any capacity-chairing a panel, acting as discussant or presenting a paper. This rule applies to APSA Program Committee panels, APSA Organized Section panels, and Unaffiliated Group panels.

If you apply to several sections, please inform each section chairperson that this is a multiple application. Also, in that case, please notify the other section chairpersons as soon as you have accepted an invitation for participation in another section.

\section{Call for Papers}

There are two unusual features of this year's program. Organized sections of the Association are for the first time taking responsibility for panels in their subject matter as integral parts of the Program Committee. And there will be six series of panels focused on special themes: Thomas Hobbes, The French Revolution, Political Science in Washington. The Civil Rights Act of 1964, The Bill of Rights, and Party Realignment.

In most other respects, the program for 1989 will remind political scientists of the programs of other years. The maintenance of continuity is, after all, part of the joy of associating with such a well-loved institution as the APSA annual meeting. Section leaders, each of whom is well qualified to give leadership in his or her respective field of competence, will announce their own proposed programs below. Please also attend to the announcement on general ground rules which the national office enforces at the direction of the Council of the Association.

Section I. Applied Political Science. Howard J. Silver, Consortium of Social Science Associations, 1625 I Street, NW, Suite 911, Washington, DC 20006; (202) 887-6166.

Panels in this section should focus on how our political science training is applied in government at all levels, the non-profit sector including academia, and the forprofit sector. Interpret "applied political science" as broadly as you desire. Training of political scientists in the application of their knowledge can also be a focus. Ap- 